\title{
DIE STAND VAN DIE OU-TESTAMENTIESE WETENSKAP, INSONDERHEID IN SUID-AFRIKA
}

Dit is nou honderd en twee jare gelede dat die eerste en enigste deel van Renan se Histoire générale et système comparé des langues sémitiques die lig gesien het. Vir sy tyd was dit 'n standaardwerk en in my jeug moes ons dit nog bestudeer, hoewel dit toe al reeds op heelwat punte verouder was. Dit was bv. vir ons snaaks om te lees hoe Renan se skepsis teenoor die ontsyfering van die spykerskrif so ver gegaan het dat hy selfs geneig was om die Semitiese karakter van die taal van die Assiriese inskripsies te ontken. Selfs die grootste geleerde bly die kind van sy tyd, en deel die wantroue wat die eie tyd gewoonlik teenoor nuwe studievelde koester. Daardie selfde skepsis kom ook tot uiting in Renan se beskouing van die Ou-Testamentiese studies van daardie tyd. Hy vermeld hoe 'n jong hoogleraar, eers te Rostock, vervolgens te Erlangen, probeer om deur sy studies en kommentare nuwe lewe in 'n so afgeslote en uitgeputte wetenskap as die Ou-Testamentiese eksegese in te blaas. Daardie jonge hoogleraar is Franz Delitzsch, die geleerde wat ons gewoonlik, in onderskeid van sy by Ou-Testamentici minder gewilde seun, die ,ou Delitzsch" noem. Volgens Renan was dit omtrent die midde van die vorige eeu 'n hopelose onderneming om nog te probeer op die terrein van die uitlegkunde van die $\mathrm{Ou}$ Testament iets nuuts voor die dag te bring. Alles wat gesê kon word, was reeds gesê.

Teen die einde van dieselfde eeu hoor ons 'n uitlating wat min of meer in dieselfde rigting wys. As Wellhausen die resultate van die literairhistoriese skool-ons noem maar net die name van Vatke, Graf en Kuenen-met sy briljante styl in 'n reeks van opsienbarende boeke neergelê het, verklaar hy omtrent die jaar 1890 in 'n vertroulike gesprek: "Ich habe das Alte Testament etwas satt bekommen", en inderdaad bring die laaste dekades van sy lewe in hoofsaak Arabistiese en Nieu-Testamentiese studies. Op die gebied van die Ou Testament was volgens sy mening die laaste woord gesê, en daardie laaste woord was sy woord. Hom het die tragiese lot getref dat amper al die vakgenote deur hom oortuig was. Orals het hy sy eie stem gehoor. As Stade se Geschichte des Volkes Israel in 1887 verskyn, weier Wellhausen om die boek in die Zeitschrift für die Alttestamentliche Wissenschaft te bespreek, want, so sê hy, „Selbstrezensionen schreibe ich nicht".

Sou daar iemand wees wat nou, honderd jaar na Renan, vyftig jaar na Wellhausen, sou durf beweer dat die laaste woord oor die Ou Testament, of selfs oor 'n onderdeel daarvan, gespreek is? Dis nouliks denkbaar dat so iemand êrens in hierdie wêreld gevind kon word. Die geweldige uitbreiding van studie- en vergelykingsmateriaal deur die ontsluiting van die ou nabye Ooste; die stortvloed van nuwe denkbeelde, visies en metodes; die steeds verder gaande verfyning in woord- en begripsbepalings--al dit en nog veel meer gee ons eerder die gevoel dat die Ou-Testamentiese wetenskap nog maar net aan die begin van sy ont- 
wikkeling staan. En die opbloei van die belangstelling, nie maar net by die vakgeleerdes, maar ook by wat ons met 'n onaangename term die leke noem, terwyl ons tog vir die publikasie van ons werke vir 'n groot deel van daardie belangstelling afhanklik is-daardie opbloei wat van 'n uiters middelmatige werk oor die argeologie van die Ou Testament 'n ,, best seller" kan maak-daardie opbloei bewys wel dat die wêreld in die algemeen nog nie bereid is om Wellhausen se woorde "Ich habe das Alte Testament etwas satt bekommen" te herhaal nie.

In dieselfde rigting wys die oprigting in 1950 van die „International Organisation of Old Testament Scholars"; die bestaan van Ou-Testamentiese werkgeselskappe in Engeland, Frankryk, Duitsland, Nederland en wellig nog heel wat ander lande; die verskyning van periodieke soos Vetus Testamentum en Oudtestamentische Studiën langs die ou Zeitschrift für die Alttestamentliche Wissenschaft; die feit dat tydskrifte soos die Rerre Biblique die Joumal of Biblical Studies, die Biblische Zeitschrift, Biblica, Verbum Domini, Bulletin of the American Schools of Oriental Research, The Biblical Archaeologist vir minstens die helfte met Ou-Testamentiese studies gevul is; en tenslotte ook $\mathbf{u}$ aanwesigheid hier te Pretoria tot bywoning van die eerste byeenkoms van die Ou-Testamentiese werkgemeenskap in Suid-Afrika.

Ons wil daardie laaste feit sekerlik nie oorskat nie; ons is daarvan bewus dat ons aantal nog klein, ons bekendheid in die wetenskaplike wêreld nog gering is. Nietemin is die oprigting van ons werkgemeenskap om twee redes van belang; nie maar net om die eerste, wat ons reeds genoem het, naamlik dat dit bewys dat die belangstelling in die OuTestamentiese studie groeiende is nie, maar ook omdat dit 'n voorbeeld is van 'n verskynsel waarop ek in die algemeen $u$ aandag wil vestig, naamlik die grotere verspreiding van die aandag vir hierdie tak van wetenskap oor die lande van die wêreld. Op hierdie punt sien ons 'n aanmerklike verskil tussen die toestand nou en 'n eeu of 'n halwe eeu gelede. Dit kan nie ontken word nie dat by die begin van hierdie eeu die sentrum van die studie van die Ou Testament in Duitsland gelê het nie. Die Duitse literatuur was oorheersend in hierdie vak. In Sellin se Einleitung in das Alte Testament, waarvan die eerste druk in 1910 verskyn het, begin die literatuuropgawe met die trotse sin: „Wir besitzen in Deutschland fünf grosse evangelische Kommentarwerke zum ganzen Alten Testament." In later drukke het dit deur die verskyning van die Handbuch zum Alten Testament selfs tot ser geklim, en in 'n noot aan die einde van die opgawe word dan nog twee grote Duitse series van Rooms Katolieke kant daaraan toegevoeg. Geen van die ander lande kon op dergelike prestasies roem nie. Die Angelsaksiese taalgebied het nog die digste daarby gekom, veral danksy die International (dit wil sê Britse en Amerikaanse) Critical Commentary. In Frankryk het wel op afsonderlike boeke kommentare verskyn wat geheel op dieselfde hoogte as die werke van Duitse vakgenote gestaan het-ek 
noem as 'n uitstekende voorbeeld Lagrange se Le livre des Juges traduit et commenté-maar geen reeks wat met die Duitse series vergelykbaar was het daar die lig gesien nie. In België was Hoonacker 'n eensame figuur; die meeste Nederlandse Ou-testamentici het in hierdie periode sterk onder die invloed van die Duitse kollegas gestaan, en dieselfde geld ook van die skaarse beoefenaars van ons vak wat in Switserland en die Skandinawiese lande aangetref is; verskillende van hulle het trouwens aan een of meer van die Duitse kommentarereekse meegewerk, en dan natuurlik ook in die Duitse taal. Met 'n bietjie oordrywing sou mens kan beweer dat ' $n$ halwe eeu gelede kennis van die Duits minstens so belangrik vir die studie van die Ou Testament was as kennis van die Hebreeus. So is dit ook begryplik-al het ek op 'n ander plek daarteen geprotesteer-dat die mooie werk van H. J. Kraus, Geschichte der historisch-kritischen Erforschung des Alten Testaments, wat die vorige jaar verskyn het, vir die laaste honderd jaar amper net met die Duitse studie rekening hou.

Teenwoordig is die situasie egter heeltemal anders. Al bly Duitsland met geleerdes soos Eissfeldt, Noth, Rudolf, Galling. series soos HZAT en Das A. T. Deutsch, en 'n tydskrif soos die $Z A W$, van veel belang, ons kan tog sê dat die beoefening van ons vak hom oor 'n groot deel van die wêreld uitgebrei het, en dat dit nie meer so gemaklik as vroeër is om 'n bepaalde land as sentrum vir daardie arbeid an te wys nie. Ons dink in die eerste plaas aan die groot plek wat die Verenigde State van Amerika teenswoordig in ons studie inneem. Wel was hulle, soos ons reeds by die vermelding van die International Critical Commentary opgemerk het, ook tevore wel verteenwoordig, en ons wil ook 'n vertederde gedagte wy aan die uitgawe van The sacred books of the Old Testament, beter bekend as die .,Reënboogbybel", waarvan die hoofredakteur, Paul Haupt, trouens in Duitsland gekore en getoë was, maar hierdie eerste pogings is nie vergelykbaar met die groot prestasies wat teenswoordig van oor die Atlantiese Oseaan tot ons kom. Dit het geen sin om baie name op te som nie; elkeen dink onmiddellik aan Albright, Burrows, Wright en soveel meer manne met wêreldfaam. Dit hang vermoedelik wel saam met die op die praktyk gerigte struktuur van die Amerikaanse mentaliteit dat dit veral die argeologiese werk is wat hulle boei; eienaardig is dit om daarlangs in die veelgelese Introduction to the Old Testament van Pfeiffer 'n soort van renaissance van die Duitse denkbeelde van die begin van hierdie eeu te aanskou.

Wanneer ons spreek oor die uitbreiding van die Ou-Testamentiese studies oor die wêreld, dink ons in die tweede plaas aan die belangrike plek wat die geleerdes uit die Skandinawiese lande-waarby ons dan Finland min of meer kan insluit-op ons terrein inneem. Ons het daar reeds op gewys dat ' $n$ halwe eeu gelede Skandinawië as 'n randgebied van die Duitse wetenskap beskou kon word. Daar is, glo ons, maar betreklik min mense wat daarvan bewus is dat ' $n$ verdienstelik geleerde soos Buhl, die bewerker van die later drukke van Gesenius se Handwörterbuch, te Kopenhagen gebore is en die grootste deel van sy akademiese loopbaan 
in Denemarken volbring het. Heel anders is die situasie tans. Ons weet almal van die Skandinawiese skool van Ou-Testamentiese ondersoek, en hoewel daar grote verskille wat betref aanpak en resultate is, bv. tussen Bentzen, Mowinckel, Pedersen of Engnell, is dit tog wel seker dat die geleerdes uit die noordelike lande 'n eie tipe vertoon, vir 'n belangrike deel onafhanklik van die Duitse wetenskap. Hulle maak daar ook geen geheim van nie, dat die eerste impulse tot hul besondere anpak nie uit die Ou-Testamentiese wetenskap as sodanig gekom het nie, maar uit die breëre terrein van die godsdiensgeskiedenis, en die nog breëre van die studie van minder ontwikkelde kultuurkringe. Dis genoeg om hier die groot name van die godsdienshistorikus Söderblom en die Germanis Grönbech te noem. Egter bewaar die Skandinawiese skool by sy eie aard en sy trots op sy prestasies gelukkig tog die kontak met die vakgenote uit minder noordelike streke en die Ou-Testamenticus wat 'n bietjie opsien teen die leer van Deens, Noors en Sweeds sien met dankbaarheid dat die hoofwerke van die noordse korifeë ook in Duitse of Engelse vorm beskikbaar is. In die laaste tyd oorweeg die Engels, en dit vermoedelik nie maar net uit politieke oorwegings nie, maar ook op grond van 'n duidelike affiniteit met die Engelse "myth and ritual" skool, waarvan Hooke die vernaamste exponent is.

In Engeland sien ons trouens oor die algemeen 'n veel groter selfstandigheid teenoor die Duitse Ou-Testamentiese wetenskap as vyftig jaar gelede. 'n Uitmuntende filoloog soos Driver, 'n skerpsinnige historikus as Rowley, manne wat soos Oesterley en Robinson hul spore op die gebied van inleiding en uitlegkunde verdien het, gee Brittanje 'n eie plek op ons studieterrein. Hier is dit veel moeiliker as by die Skandinawiërs om 'n samevattende karakteristiek van die geheel te gee. Die gemeenskaplike lê wellig meer op die terrein van die goeie smaak, die aangename leesbaarheid, die rustige besonnenheid en die sin vir die realiteite van die lewe, as in bepaalde opvattings en teorieë.

Ook van Switserland geld dit dat dit nie meer as net 'n randgebied van die Duitse wetenskap aangesien kan word nie. Opmerklik is daar die belangstelling vir die teologiese beskouing van die Ou Testament. Ons kan dit wellig verklaar, gedeeltelik as invloed van, gedeeltelik as 'n reaksie op--en dus tog ook invloed van-die anwesigheid in Switserland van die grootste protestantse dogmatikus van hierdie eeu. In ieder geval is dit opmerklik, nie maar net dat twee uitvoerige werke met die titel Theologie des Alten Testaments van die hand van Switserse geleerdes, nl. van Eichrodt en van Köhler, die lig gesien het nie, maar ook dat die studies van W. $\checkmark$ 'ischer oor Das Christuszeugnis des Alten Testaments uit Switserse omgewing voortgekom het. Daarlangs mag ons egter nie vergeet dat ook meer histories en literair georiënteerde werke in groot aantal uit Switserland tot ons gekom het; ek noem die name van Baumgartner, Zimmerli, Jenni, Stamm, Fohrer, en vergeet waarskynlik nog meer.

Opmerklik is die opbloei van die Ou-Testamentiese studie in Frankryk. Dit was reeds aan die begin van hierdie eeu voorberei deur manne 
as Lagrange, Vincent en Dhorme, maar is veral gestimuleer deur die nuwere ontwikkelinge in die Rooms Katolieke Kerk en die argeologiese arbeid van die Dominicaanse École Biblique. Sonder dat ons iets af wil doen van die waarde van ander Bybelse tydskrifte sal ons tog moet erken dat hulle nouliks kan kompeteer met die Revue Biblique, wie se argeologiese oorsigte, boekbesprekings en selfstandige artikels op 'n onveranderde hoë peil staan. 'n Man as De Vaux is as Palestinakenner amper ongeëwenaar. Verder noem ons die werke van Cazelles, wat Frankryk in die Vetus Testamentum verteenwoordig; die serie van Parrot, Bible et Archéologie; verskillende series Bybelverklaring; en, ofskoon hy sowel Frankryk as die Katolieke Kerk vaarwel gesê het, Barrois met sy pragtige Manuel d'archéologie biblique.

Maar ook ander Romaanse lande laat hul nie onbetuig nie. Italië wat tydens die vorige geslag reeds op 'n Assiroloog van die formaat van Furlani kon boog, besit tans in Moscati 'n Semitis wie se werke, eenvoudig geskryf en met goeie verwerking van die vakliteratuur, oor die hele wêreld aandag trek. Die geskiedenis van Israel het hier in Ricciotti 'n noukeurige en besonne beskrywer gevind, en die Pouslike Bybelskool te Rome is nie in die laaste plek nie deur die voortreflike serie handboeke wat onder die algemene titel Analecta Orientalia die lig sien, by alle vakgenote vermaard. Daarlangs tref ons die laaste dekades ook nou en dan studies en publikasies van Spaanse kant, in die besonder van Fernandez.

Die feit dat Tsjego-Slowakye aan die ander kant van die Ystergordyn lê, belet nie dat nou en dan berigte oor Ou-Testamentiese studies in daardie land ons bereik nie. Aan die Oosterse Instituut te Praag word die Ou Testament, wat nog altyd 'n belangrike bron vir ons kennis van die antieke ooste bly, nie verwaarloos nie. Wie gereeld die voortreflike tydskrif Archiv Orientalni insien, sal daar telkens op Ou-Testamentiese bydrae van die hand van geleerdes soos Bic of Segert stoot, en die regsvergelykende studies van Klima of die Babiloniese werk van Matouš bewys dat hierdie leerlinge van Hrozny die werk van die ou meester met onverminderde geeskrag voortset. Moeiliker is dit om op die hoogte te kom van wat in Rusland self op ons gebied aangaan. Hier staan ons nie maar net teenoor die Ystergordyn nie, maar ook en veral teenoor die feit dat die Sowjetgeleerdes in hoofsaak in die Russies publiseer. Ons het egter wel iets verneem van Deuteronomiumstudies op 'n sosiologiese basis met die Marxistiese geskiedbeskouing as uitgangspunt.

In Asië is daar een land waar die studie van die Ou Testament 'n ongeëwenaarde bloeiperiode deurmaak. Ons bedoel natuurlik die staat Israel. Dit is die enigste land in die wêreld waar die Ou Testament in sy Hebreeuse vorm deel uitmaak van die leerplan van die skole. Die argeologiese ondersoek het ook gedurende die resente oorlogstoestande reëlmatig roortgang gevind en dis begryplik dat nie maar net die streng ortodokse Bar-Ilan Universiteit, maar ook die meer sekulêr geörienteerde Universiteit van Jerusalem groot aandag aan die studie van die Ou Testament gee. Behalwe ander dinge is dit mos ook die oudste en mees betrou- 
bare dokument van die lange voorgeskiedenis van die jonge staat. Manne soos Sukenik, die kenner van die Palestynse argeologie; Torczyner, die uiters oorspronklike behandelaar van probleme van inleiding en eksegese; Avi-Jona die outeur oor die historiese geografie van Palestina; en baie meer wat ons op die oomblik nie almal wil opsom nie, het aan die Hebreeuse Universiteit ' $n$ klinkende naam op ons studieterrein verskaf. Ons dink ook nog aan die Semitis Cassuto, nou helaas netsoos Sukenik nie meer onder die lewendes nie. 'n Falanks van jongere figure set die tradisie voort.

Dit het $\mathrm{u}$ miskien opgeval dat ek tot nou toe nie oor Nederland gepraat het nie. Dit was waarlik nie omdat daarvan niks te sê was nie. In Vriezen besit Nederland 'n figuur wat internasionaal gewaardeer word, veral om sy Hoofdlijnen der theologie van het Oude Testament, wat ook in Duitse vertaling verskyn het. Ook De Boer word in die wêreld buitekant Nederland gewaardeer, nie maar net om sy tekskritiese en andere studies nie, maar ook om sy organisatoriese vermoë, die stukrag agter die Oudtestamentische Studiën en die International Organisation of Old Testament Scholars. In Monseigneur Alfrink het ons die seldsame voorbeeld van 'n Oud-Testamentikus wat 'n aartsbiskoplike setel (die van Utrecht) bestyg het. Figure as Simons, Van der Ploeg en Van den Born, alsmede die Vlaminge Coppens en De Langhe getuig van die werkkrag en bekwaamheid van Nederlands sprekende Katolieke bestudeerders van die ou literatuur van Israel en sy nabure. Andersyds is die serie Commentaar op het Oude Testament 'n monument van die eksegetiese arbeid van die Gereformeerde skool, waar nou manne soos H. N. Ridderbos en Gispen die leiding het. Ons het egter die Nederlandse taalgebied tot die laaste bewaar omdat dit 'n oorgang vorm tot Suid Afrika, waar figure soos Gemser en Kroeze, en miskien ook nog enigsins die skrywer van hierdie bladsye, geprobeer het om iets van die Nederlandse deeglikheid en besonnenheid op hierdie gebied oor te plant. $\mathrm{Na}$ die min of meer geïsoleerde en heftig omstrede figure van Biskop Colenso in die vorige eeu, en J. du Plessis in die eerste dekades van die teenswoordige, het nou 'n hele generasie van Afrikaanse Oud-Testamentici opgestaan. Dis onnodig om in hierdie kring name te noem. Ons ken mekaar en nieteenstaande verskil in opvattings en metodes het ons mekaar leer waardeer, insonderheid by ons gemeenskaplike werk aan die groot uitgawe van Die Afrikaanse Bybel met kanttekeninge, waarvan die eerste deel binne enkele maande verwag word. Dis nie sonder 'n sekere trots en voldoening nie dat ons by hierdie eerste byeenkoms van die Afrikaanse Oud-Testamentiese werkgemeenskap dit kan uitspreek dat ons besig is om die Unie van Suid Afrika en die Universiteite van Stellenbosch, Potchefstroom en Pretoria op die kaart van die Oud-Testamentiese wetenskap te plaas.

Langs die geografiese uitbreiding van die Ou-Testamentiese wetenskap wil ons ook wys op 'n ander vorm van ekspansie, wat wellig in die toekoms nog veel belangriker as die puur geografiese sal blyk, naamlik oor die 
gebied van die verskillende geestesstrominge. Ook hier sou ons 'n vergelyking met 'n halwe eeu gelede kan maak. Toe was die studie van die Ou Testament in hoofsaak in hande van die liberale Protestantisme. Dit was 'n uitsondering as iemand van buite daardie noodsaaklik vaag begrensde kring internasionale en interdenominasionale erkenning gekry het. Merkwaardig is dit ook om te sien hoe herhaaldelik manne wat in hul diepste oortuigings seker geen kinders van die godsdienstige liberalisme genoem kon word, tog in hul Oud-Testamentiese arbeid volkome deur die in die liberale Protestantisme geldende onderstellinge beheers is. Ons dink aan 'n figuur soos Wildeboer, in wie se lewe hierdie tweespalt amper tragiese afmetings aangeneem het. Ons vergeet ook nie hoe die encycliek Pascendi dominicae gregis en die daaruit gekristalliseerde anti-moderniste-eed dergelike figure in die Roomse Kerk in die ongelyk gestel het nie.

In ons tyd lê die verhoudings totaal anders. Ons kan sekerlik nie sê dat die Oud-Testamentiese studie die prerogatief van 'n bepaalde kerklike of godsdienstige rigting is nie. Langs geleerdes wat blykens hul werke nog die vrysinnige houding teenoor die kanon van die Ou Testament inneem, staan ander wat eerder ortodoks genoem kan word, weer ander wat die Neo-calvinistiese opvattings verdedig, en selfs, nog ter regtersyde daarvan, enkele verteenwoordigers van wat ons gemakshalwe met die Amerikaanse term die fundamentalisme noem. In hierdie verband is dit leersaam om ' $n$ lys van Kerke en ander instansies wat meewerk aan die instandhouding van die American School of Oriental Research, te beskou. Ons vind hier nie alleen die van ouds erkende en gerespekteerde Kerke, maar ook groeperings wat sowel op die vasteland van Europa as ook hier in Afrika nog onder die sektes gereken word, soos Baptiste en Sewende Dagsadventiste, en 'n mens kry die indruk dat in derglike groepe ons wetenskap, soos die teologiese arbeid in die algemeen, veel hoër gewaardeer word as wat in die begin van hierdie eeu gewoonlik die geval was. Twee faktore het vermoedelik tot hierdie nuwe toestand aanleiding gegee; aan die een kant is daardie welbekende proses waarneembaar wat altyd weer daartoe sal lei dat 'n groep, wat in opposisie tot die gelyktydige kulturele lewe geneig was om groot kultuurterreine te verwaarloos, na 'n paar geslagte ontdek dat om te kan voortbestaan 'n kulturele agterstand ingehaal moet word. Aan die ander kant is deur die ontwikkeling in die nuwere wysbegeerte duidelik aangetoon dat wetenskaplike vooronderstellings inderdaad slegs onderstellings en werkhipoteses is, en dat dit denkbaar en moontlik is dat met ander onderstellings en metodes ander resultate bereik word wat uit wetenskaplike oogpunt nie hoef agter te staan by wat vroeër op wetenskaplike terrein as alleensaligmakend beskou is nie.

Wellig nog opmerkliker is die groot belangstelling vir die Ou-Testamentiese ondersoek in Rooms Katolieke kringe. Dit het eers gelyk of die instelling van die Pouselike Bybelkommissie en sy antwoorde op vrae van die Heilige Stoel oor bepaalde literair-historiese vrae-soos bv. die outentisiteit van Jes. 40-66-'n domper op die Rooms Katolieke Bybelondersoek sou set. Sake het egter anders verloop as wat voorsien is. In 
ons tyd beleef ons 'n bloei van die Roomse Bybelstudie soos in baie eeue nie gesien is nie. Dis merkwaardig om te sien hoe die maatreëls wat eers suiwer negatief van aard gelyk het, geneem na aanleiding en ter bestryding van die modernisme in die Roomse Kerk, in die loop van hierdie eeu gedurig meer in positiewe rigting, tot bevordering van die Bybelstudie en die wetenskaplike ondersoek van die Heilige Land en die omwonende volke gewend is. Die pouselike Bybelkommissie het in die loop van die jare steeds minder vrae ter beantwoording gekry, maar institute vir die wetenskaplike bestudering van die Heilige Skrif is kragtig deur die leiding in die Roomse Kerk bevorder. Ons het reeds met bewondering van die Pouselike Bybelinstituut te Rome en van die École Biblique te Jerusalem melding gemaak. Daarby tref dit die buitestaander, wat nog altyd die eerste antwoorde van die Bybelkommissie in sy geheue ronddra, hoeveel vryheid die Roomse Kerk aan sy geleerdes toestaan. In 'n kommentareserie soos Die Heilige Schrift des Alten Testamentes word nie maar net vry spel aan tekskritiek gegee nie, maar kom dit ook tot merkwaardige uitsprake op literair-kritiese terrein. Terwyl die antwoord van die pouselike Bybelkommissie van 27 Junie 1906 die mosaiese oorsprong van die Pentateuch handhaaf, word dit nou so geinterpreteer, dat „die Pentateuch die produk is van die religieuse ontwikkeling in die openbaringsvolk van Moses tot op die tyd van die Babiloniese ballingskap" (Hoberg, gesiteer volgens H. Junker, Das Buch Deuteronomium, p. 16). Nog heel wat verder gaan die vryheid as 'n Roomse geleerde soos A. van den Born in 'n artikel in 'n Roomse tydskrif soos Studia Catholica die stelling verdedig dat die hele boek Esegiël 'n pseudepigrafiese geskrif uit die tweede helfte van die ryfde eeu is.

Ook buite die Christendom het die Ou Testament verhoogde belangstelling gekry. Ons dink aan die groot aktiwiteit van Joodse outeurs, van allerhande rigting, op hierdie gebied. In die negentiende eeu was Joodse beoefenaars van die Ou-Testamentiese wetenskap opvallend skaars. 'n Man soos Geiger (Urschrift und Uebersetzungen der Bibel, 1857) was in daardie tyd 'n eenling. Die meeste Joodse geleerdes het hul meer met die "Wissenschaft des Judentums" besig gehou as met die studie van die Ou Testament, wat gewoonlik aan stigtelike beskouinge oorgelaat is. Totaal anders is die situasie vandag. Dit val, wanneer 'n mens ' $n$ jaargang, bv. van Vetus Testamentum, deurblaai, onmiddellik op hoe hoë persentasie van die bydraes van Joodse hand is. Hierby tref ons die grootste verskeidenheid aan. Daar is geleerdes wat hul aansluit by die tradisies wat van die vroeë middeleeue af aan oor die Bybel in omloop was; daar is wat hulle aansluit by die metodes en opvattings wat ons in die algemeen as "literair-krities" kan kenskets; daar is ook wat probeer om totaal nuwe oplossings te vind. Gesien die op die praktyk gerigte aard van die Joodse religieuse sisteem is daar in die sinagoge geen sprake van 'n leergesag oor teoretiese sake nie; nog veel minder kan die blote feit dat iemand van Joodse afstamming of ' $n$ burger van die staat Israel is, hom in 'n bepaalde rigting by sy wetenskaplike werk oor die „Tanach" stu. Ons 
kan in hierdie verband dus beter van die groeiende invloed van Joodse geleerdes as van die van die Jodendom praat. Die bydrae van Israel sowel in die Diaspora--ons dink bv, aan die voortreflike studies in die Hebrew Union College Annual-as in die eie staat op die ou geheiligde bodem, word met dankbaarheid deur die vakgenote uit ander kring erken. Hierdie dankbaarheid word egter wel enigermate getemper deur die op sig self seer begryplike neiging om die vrug van die ondersoek neer te lê in die eie taal, wat ook die taal van die voorwerp van ondersoek is, maar nietemin in sy moderne vorm heel wat struikelblokke bied vir wie beter tuis is in Jesaja of Jeremia as in Bialik of Alterman.

$\mathrm{Na}$ die uitbreiding oor die lande van die wêreld en die oor die geestesgroeperinge van die mensheid wil ons hier ook 'n enkel woord wy an die expansie van die voorwerp van ons studies self. Die tyd is onherroepelik verby dat die Ou Testament as ' $n$ geisoleerde monument van die verlede beskou kon ward, 'n eensame rotsgevaarte in 'n verder onbekende streek. Dit is nie meer moontlik om net Ou-Testamentizus te wees nie, en nie tewens semitis en argeoloog nie. Dit kan ons teenswoordig gebeur dat ons, vermoeid deur die onafsienbare moontlikhede van ons studieterrein, 'n oomblik met heimwee terugdink aan die tyd, nog nie eens so ver agter ons, dat iemand met 'n redelike kennis van oud-Hebreeus toegerus, hom kon aangord om die probleme in verband met die $\mathrm{Ou}$ Testament te gaan oplos. Dit is nou ondenkbaar dat iemand homself 'n Ou-Testamenticus noem sonder bv. in Babilonies en Ugarities gekonfyt te wees. Wil hy hom op die ouer geskiedenis werp, dan moet hy seker Egipties ken; wil hy die koningskap in Israel of die wetgewing ondersoek, dan sal hy weldra in Hetitiese en Sumeriese gegewens gaan onderduik; die Suid-Arabiese terminologie in verband met Kultussake vra steeds meer om ons aandag; vir die grammatika en lexikografie bly Arabies en Aramees in sy twaalf vertakkings 'n noodsaaklikheid. Vir die voortsetting van die tekskritiese arbeid-in wese tog die grondslag van al ons werkmoet die wetenskaplike werker behalwe die Grieks en Latyn, wat ons by die Hebraicus onderstel, en die Aramees wat ons reeds genoem het, by voorkeur ook iets van Kopties en Geëz weet, en selfs Armeens, Georgies en Goties is nie geheel sonder belang vir die studie van die teksoorlewering nie.

Die ontsluiting van nuwe kultuurgemeenskappe uit die ou Ooste verryk ons kennis, maar dwing ons tegelykertyd tot 'n steeds verdergaande verbreding van ons studieterrein. Ons noem net 'n paar name, sonder verder op die probleme in te gaan: elk van hulle vereis op sy minste 'n afsonderlike boek. Die gegewens van Nuzi laat ons allerlei verskynsels van die Ou-Testamentiese regslewe, insonderheid in die patriargetyd, onder 'n nuwe lig sien; die tekste van Mari, in 'n steeds toenemende stroom van publikasies toeganklik, het van groot betekenis geword vir ons verstaan van die verskynsel van die profesie as sodanig; die Ugaritiese literatuur gee ons merkwaardige toeligtings op die religieuse digvorme van 
die Ou Testestament, insonderheid Psalms. So is deur die ontdekkinge van die laaste twintig jaar ons studie van die drie hoofdele van die Tanach, Tora, Nebiïm en Chetubim, hernuut.

Teenoor hierdie groot toevloed van nuwe gegewens tree altans vir die gevoel van die skrywer van hierdie bladsye die verskuiwing van metodes enigermate in die agtergrond. Die literair-historiese metode het nou tot die ,traditionsgeschichtliche" (watter woord!) ontwikkel; die „formgeschichtliche" loop uit op ondersoekings na metrum en strofebou; die godsdienshistoriese vra minder om die toepassing van onderstelde godsdiens-historiese ontwikkelingswette op die afsonderlike religie van Israel, maar probeer veeleer om die ouer vorme van Hebreeuse kultus in die „pattern" van 'n algemeen ou-Oosterse lewensbeskouing te bring-of moet ons sê: wring? Dit mag miskien ietwat ligsinnig klink, maar vir die referent lyk dit dikwels of die ontdekking van 'n handvol ostraka of spykerskriftablette van veel meer belang is as die ontwikkeling en toepassing van weer 'n nuwe metode en die stigting van 'n nuwe skool. Dit laat ' $n$ mens tog wel 'n bietjie dink aan die opmerking van Schopenhauer: „Professorenphilosophie für Philosophieprofessoren”. Dit hoef egter nie te slaan op die neiging om die Ou Testament veral ook uit 'n sosiologiese oogpunt te bestudeer nie; 'n heldere insig in die maatskaplike lewe van Israel en die sosiale gelaagdheid van die bevolking van Palestina in Bybelse tyd is 'n noodsaaklikheid sowel vir die beoefening van die uitlegkunde as ook vir die skildering van die historiese ontwikkeling.

Die grootste ontdekking op Bybelse gebied wat hierdie eeu gedoen is, was ongetwyfeld die vonds van die rolle en fragmente by Qumraan en in die nabye Wadi alMurabaät en Khirbet Mird. Dit stel alle skrifvondse wat tot op vandag in Palestina gemaak is in die skaduwee. Die werk van die publikasie sal sekerlik nog wel tien jaar vat, en die bestudering van die geheel bied genoeg stof vir die res van hierdie eeu. Nou reeds is die getal van die publikasies onoorsienbaar. Daar het 'n Bibliographie zu den Handschriften vom Toten Meer van die hand van Chr. Burchard verskyn, wat ruim honderd bladsye groot is. Gelukkig is dit vir ons nie nodig om alles te lees wat verskyn het nie! 'n Groot deel van die opgesomde artikels is nou alreeds verouder, en by die boeke wat oor hierdie onderwerp verskyn, is daar ook wat uitmunt deur dilettantiese fantastery, soos die van Wilson en die van Powell Davies.

Die Ou-Testamenticus rig hierby sy aandag natuurlik in die eerste plaas op die twee Jesajarolle, waarvan die waarde vir die tekskritiek nòg oorskat, nòg onderskat mag word. Tekskritiese betekenis het ook die aanhalings in die Habakukkommentaar, maar wellig nog veel meer die duisende fragmente van Bybelse tekste wat in die verskillende grotte gevind is en gepubliseer gaan word in die groot serie Discoveries in the Judean Desert, waarvan die eerste deel, van die hand van Barthélemy en Milik, in 1955 die lig gesien het. Die voorkoms bv. van 'n Hebreeuse teks van groot stukke van Samuel, wat nouer verwant is aan die Septuaginta van daardie boek as aan die Masoretiese teksvorm, is van die uiterste betekenis 
vir die tekskritiek in die algemeen. Minder belangrik mag vir ons op die eerste aanblik die kommentare op stukke uit die profete en psalms lyk, al bly dit tog interessant om te sien hoe 'n geslag wat twee duisend jaar digter by die Ou Testament gestaan het as ons, dit gelees en verstaan het. Dieselfde geld ook van die parafrase van Genesis, die werk oor die lewe van Dawid en derglike skrifture. Maar ook ander boeke, wat geen direkte relasie met die geskrifte van die Bybel het nie, kan van belang wees vir ons kennis van die Hebreeuse grammatika en lexicografie; mede op grond van die oortalryke sitate is hul tekskritiese betekenis ook nie te verwarloos nie.

Die Dooie Seemanuskripte bring ons ook op 'n terrein wat feitlik meer tot die studieveld van die Nieu-Testamentici as tot die van die Ou-Testamentici behoort. Dit kan ons 'n sekere voldoening gee om op te merk dat die Nieu-Testamentici van die toekoms wellig minder Atties en meer Hebreeus en Aramees sal moet gaan studeer. Soos die toestand nou is, sal hulle ons hulp nie kan ontbeer nie. Daardie hulp word ook volvaardig aangebied; ek dink bv. aan 'n uitmuntende werk soos die van Burrows, The Dead Sea Scrolls, met sy versigtige afweging van argumente en betroubare vertalings. Veel bystand kan ook verwag word van die aangekondigde serie werke onder redaksie van Van der Ploeg; daarin sal al die rolle en belangrike ander dokumente in vertaling verskyn. Die naam van die redakteur staan vir ons borg dat daarin betroubare wetenskaplike arbeid van die eerste rang gelewer gaan word.

Ten laatse nog 'n woord oor die stand en taak van die Ou-Testamentiese wetenskap in hierdie land self. Ook hierby onthou ek my van 'n onvrugbare opsomming van name en titels om sodoende ruimte te hou vir 'n paar opmerkinge van meer algemene aard. Afgesien van die twee figure van Colenso en Du Plessis, kan ons van wetenskaplike behandeling van Ou-Testamentiese vraagstukke, altans in gepubliseerde vorm, eers in ons teenswoordige tydvak spreek. Aan die begin daarvan staan die figuur van een, wat ons graag nog in ons midde sou sien, Berend Gemser, wat ons, al dien hy nou die universiteit van Groningen, tog nog wel as een van ons mag reken, die leermeester van amper almal in Afrika wat die Ou Testament of die Semitiese tale as studieterrein gekies het, en seker facile princeps, eerder nog as primus inter pares. Die bestaan van ons kring is bo alles aan sy geduldige, as voorbeeld inspirerende arbeid van amper dertig jaar in hierdie land te danke.

Gemser is bo alles exegeet, en dit het seker 'n stempel op die arbeid in hierdie land geset. Die meeste van ons hou hulle met exegetiese vraagstukke besig. Dis ook die gebied waar die band met die praktyk van die teologie die sterkste is. Regte uitlegging is die grondslag van die prediking en as sodanig 'n lewensbehoefte van die Kerk. Die uitgawe van die Afrikaanse Bybel met kanttekeninge kan as 'n samevatting van ons arbeid op hierdie gebied genoem word. Die exegetiese arbeid blyk nie maar net uit die vry talryke afsonderlike publikasies waarin die uitleg van 'n 
bepaalde Bybelboek gebied word nie, maar ook uit verskillende monografië oor 'n bepaalde aspek van sekere Bybelboeke of oor die omvang en betekenis van enkele Bybelse begrippe.

Minder druk word die hulpwetenskappe by die exegese beoefen. Inleidingsvrae kom wel by die exegese aan bod, maar het tot nou toe selde die voorwerp van afsonderlike publikasies geword. Dit kan weesek spreek dit nie sonder aarseling uit nie-dat hierby 'n sekere omsigtigheid ten aansien van die kerklike milieu 'n rol speel; aan die ander kant seker tog ook wel 'n Afrikaanse afkeer van teoretiese bouwerke sonder duidelik dokumenteerbare fundament. Die totale afwesigheid van tekskritiese studies is veeleer te wyte aan die feit dat ons biblioteke, wat grotendeels gedurende die laaste dekades opgebou is, daartoe nie die nodige apparaat bied nie. Waar in Afrika, om enkele voorbeelde te noem, beskik ons oor 'n eksemplaar van Field se Origenis Hexaplorum quae supersunt, oor Sabatier se Biblonum Sacrorum Versiones Antiquae, of oor die ouere uitgawes van die verskillende Targumim? 'n Onderdeel van die teologie van die Ou Testament het tot nou toe, vir sover die skrywer bekend, nog maar net een keer die voorwerp van'n afsonderlike publikasie geword. Dit hang wel saam met die geringe dogmatiese belangstelling in die algemeen.

Veel meer is gedoen aan die studie van die ou Oosterse wêreld en sy relasie met die Heilige Skrif. Die Sumeriese, Babiloniese, Ugaritiese en Moabitiese gegewens is deur Afrikaanse geleerdes behandel, so nie in hul geheel nie, dan tog ten aansien van enkele belangrike onderdele daarvan. Hierdie belangstelling is in hoofsaak letterkundig van aard. Op die gebied van die Palestynse aardrykskunde kan maar net een monografie genoem word, en aangesien dit die teofore aardrykskundige eiename behandel, is dit tog meer 'n taalkundige as 'n argeologiese ondersoek.

Dit mag ons verwondering wek dat die argeologie as sodanig nog so min belangstelling gewek het. Terwyl allerlei lande wat tydens die jongste oorlog groot verliese ook in finansiële opsig gelei het, onmiddellik daarna weer begin het met opgrawingswerk in die Bybelse lande, neem Afrika daaraan, hoewel dit as een van die ryk lande geld, nog glad geen deel nie. Die situasie is selfs nog ernstiger; toe enkele jare gelede die moontlikheid bestaan het om ' $n$ belangrike kolleksie fragmente van Dooie See handskrifte vir die som van $£ 1,500$ aan te koop, het dit weldra geblyk dat 'n derglike bedrag in hierdie land nie gevind kon word nie. Dit sal 'n deel van ons taak moet word om langs die voortsetting van ons letterkundige arbeid en die opleiding van ' $n$ tweede generasie van Ou-Testamentici ook aandag te gee aan die opvoeding van ons publiek. 